\title{
A ostensividade do voto dos parlamentares brasileiros
}

\author{
Bruno Ponich Ruzon ${ }^{1}$ \\ "O poder é tanto mais potente quanto menos se deixa ver" \\ Noberto Bobbio
}

\section{Resumo}

\begin{abstract}
O trabalho enfrenta o problema da ostensividade do voto parlamentar. Com fundamento na democracia, através da análise do ordenamento jurídico pátrio, busca-se interpretar os vários dispositivos constitucionais que regulam a votação nas casas legislativas brasileiras. Encontra-se a regra geral do voto aberto e, então, realiza-se breve estudo sobre os regimentos internos da Câmara dos Deputados e do Senado Federal, bem como das Constituições Estaduais e Leis Orgânicas Municipais. Por fim, destaca-se a tendência à ampliação das hipóteses do voto aberto.
\end{abstract}

Palavras-Chave: Votação secreta; Votação ostensiva; Voto aberto; Voto fechado; Poder Legislativo; Câmara dos Deputados; Senado Federal.

\section{Introdução}

A melhor forma de introduzir um problema científico, quando se está no campo da ciência jurídica, é revelando a sua ligação com a realidade das pessoas. O Direito não foi feito para ficar nas divagações filosóficas e abstrações alienantes, mas para explicar o que está a nossa volta, e permitir a emancipação do ser humano. Assim, é importante destacar alguns acontecimentos históricos recentes.

Em fevereiro de 2005 os deputados federais brasileiros elegeram Severino Cavalcanti (PP-PE) para a Presidência da Câmara dos Deputados ${ }^{2}$. Este representante do povo integrava o "baixo clero" da Casa, conforme expressão cunhada pela imprensa, e representaria o corporativismo, fisiologismo e conservadorismo daquele parlamento. Várias eram as críticas contra o novo Presidente da Câmara dos Deputados que, após denúncias de corrupção, renunciou ao mandato em 21 de setembro de 2005. Considerações à parte, a

Bacharel em Direito pela Universidade Estadual de Londrina. Cursando pós-graduação lato sensu de Direito do Estado, concentração na área de Direito Constitucional, na Universidade Estadual de Londrina.

2 Informações obtidas no site oficial da Câmara dos Deputados: http://www.camara.gov.br - acesso em 28 de janeiro de 2007. 
eleição de Severino Cavalcanti ocorreu mediante votação secreta, impedindo-se, assim, que os brasileiros conhecessem os seus apoiadores.

No mesmo ano de 2005, o escândalo denominado pela mídia como "mensalão" colocou vários parlamentares em destaque. Houve a cassação do mandato do deputado José Dirceu (PT-SP) em sessão extraordinária realizada em 30 de novembro de 2005, a votação foi secreta. Por outro lado, João Paulo Cunha (PT-SP), João Magno de Moura (PT-MG), Wanderval Lima dos Santos (PL-SP), José Janene (PP-PR), dentre outros, mesmo com os relatórios das investigações concluindo pela culpabilidade deles, acabaram sendo absolvidos por seus pares, sempre através de votações sigilosas. Durante estes eventos, a pergunta que incomodou a imprensa, os cientistas políticos, e a população em geral, foi: Será que todos estes acontecimentos repetir-se-iam do mesmo modo se tais votações fossem abertas? Cruamente, se os parlamentares votantes tivessem que prestar contas aos seus eleitores, será que Severino Cavalcante teria sido eleito para a presidência da Câmara dos Deputados, ou os mencionados deputados absolvidos teriam sido condenados?

Diante de tal cenário, surge o interesse pelo presente estudo. Não para responder as perguntas acima formuladas, mas para revelar, juridicamente, como o nosso ordenamento disciplina a votação nas casas legislativas brasileiras. Trata-se de questão pouco discutida no âmbito acadêmico. A doutrina jurídica parece temer tecer maiores considerações sobre o Poder Legislativo, como se apenas a Ciência Política pudesse explicar os fenômenos que ocorrem nas diversas casas legislativas espalhadas por todo o país. Enquanto é vasta a literatura sobre o Poder Executivo (destaque-se as diversas obras sobre Direito Administrativo), ou sobre o Poder Judiciário (livros nos diversos ramos do direito processual), o Poder Legislativo parece esquecido pelos juristas.

O tema não será estudado por um viés pós-positivista de vanguarda. Não se utilizará da tópica ou da jurisprudência dos valores, por exemplo. $\mathrm{O}$ alvo deste trabalho é o ordenamento jurídico, nos moldes do mais puro pensamento positivista. Obviamente, não é possível manter-se na estreitas linhas traçadas pelos juristas do século XIX, porém, não espere o leitor uma análise profunda e política sobre o problema. O objetivo é delinear os elementos normativos da questão. Portanto, o estudo terá uma tendência neopositivista, primando pela análise da legislação em vigência, sem olvidar de algumas considerações de caráter menos jurídico, necessárias, entretanto, para o desenvolvimento do raciocínio. 


\section{A vitória da democracia}

Considerando a metodologia previamente estabelecida, o primeiro passo a ser dado é em direção à Constituição Federal, pois ela está no topo do sistema jurídico pátrio. Conforme explica o professor Bobbio (1999, p. 49):

Aceitamos aqui a teoria da construção escalonada do ordenamento jurídico, elaborada por Kelsen. Essa teoria serve para dar uma explicação da unidade de um ordenamento jurídico complexo. Seu núcleo é que as normas de um ordenamento não estão todas no mesmo plano. Há normas superiores e normas inferiores. As inferiores dependem das superiores.

Nesta hierarquização normativa é a Constituição Federal que se encontra no cume do ordenamento jurídico. Daí existir o chamado princípio da supremacia da constituição, amplamente adotado no mundo ocidental:

Significa que a constituição se coloca no vértice do sistema jurídico do país, a que confere validade, e que todos os poderes estatais são legítimos na medida em que ela os reconheça e na proporção por ela distribuídos [...] todas as normas que integram a ordenação jurídica nacional só serão válidas se se conformarem com as normas da Constituição Federal (SILVA, 2001, p. 45-46).

Observando-se o texto constitucional, em busca de dispositivos que disciplinem a modalidade de votação nos parlamentos brasileiros, depara-se com um primeiro problema. Ocorre que a Constituição Federal de 1988, em plena vigência, não regulamenta minuciosamente à questão, não estabelecendo, expressamente, nenhuma regra geral sobre as votações nas casas legislativas. O que existe são alguns dispositivos esparsos, que obrigam a adoção do voto secreto em algumas hipóteses. Desta forma, resta um grande espectro de casos sem regulamentação constitucional. Ora, quando a Constituição Federal é omissa sobre uma questão, das duas uma, ou está concedendo liberdade para que o legislador infraconstitucional discipline a matéria, ou então, implicitamente, através de seus princípios, dá exatamente a medida que as leis ordinárias e complementares terão que seguir. Portanto, tem-se que verificar qual das duas hipóteses é a aplicável ao caso.

Esta análise só é possível aproximando-se da essência da Carta Magna. Esta essência está no Estado Democrático de Direito e no regime republicano, expressamente adotados pelo Poder Constituinte (artigo 1ํ, CF). Estes são valores fundamentais do 
ordenamento jurídico pátrio. São elementos que estão na raiz do pensamento jurídico contemporâneo, mas que só podem ser compreendidos se observados além da limitada visão jurídica.

$\mathrm{Na}$ literatura clássica, democracia e república confundem-se. Dependendo do pensador escolhido será uma a acepção dada a cada um dos termos (BOBBIO, 1997). Longe destas discussões, não é necessário definir democracia e república neste trabalho, pois não é este o seu objetivo. O substrato de que se precisa é de todo comum a ambas. De qualquer forma, são pertinentes, as seguintes palavras de Montesquieu (2002, p. 23) (1689-1755) "Quando, em uma república, o povo, formando um só corpo, tem o poder soberano, isso vem a ser uma democracia. Quando o poder soberano está nas mãos de uma parte do povo, trata-se de uma aristocracia" (grifos originais). De fato, nem toda república é constituída aos moldes democráticos. Observe-se que a Constituição de 1891 optou pelo regime republicano (art. 1으), mas mesmo assim o Brasil continuou nas mãos de um pequeno grupo, em uma política aristocrática/oligárquica (IGLESIAS, 1993, pp. 205-228). Também a Constituição de 1967 adotou o regime republicano (artigo 1ㅇ), o que não significou a existência de um modelo democrático. Neste sentido, é interessante destacar o aspecto democrático do atual ordenamento, que se opõe ao autoritarismo e à concentração de poder.

Através da democracia tenta-se eliminar a dicotomia governante versus governado, aproximando-se ambos. Daí existir diferentes classificações baseadas neste critério:

a) democracia direta: aquela em que os governados atuam como governantes, escolhendo as leis que deverão seguir; b) democracia semidireta: aquela em que existem representantes, o que não impossibilita a adoção de algumas práticas diretas (plebiscito, referendo, etc); e, c) democracia representativa (parlamentar ou indireta): aquela em que os representantes têm exclusividade nas decisões políticas. As sociedades ocidentais modernas inclinaram-se à democracia representativa. Segundo Dalmo de Abreu Dallari (2001, p. 155):

A impossibilidade prática de utilização dos processos da democracia direta, bem como as limitações inerentes aos institutos de democracia semidireta, tornaram inevitável o recurso à democracia representativa, apesar de todas as dificuldades já reveladas para sua efetivação. 
No caso brasileiro, embora o discurso oficial e dogmático informe que impera a democracia participativa, a história recente desacredita tal posicionamento e revela que, materialmente, prevalece no Brasil a democracia representativa, isto porque os instrumentos participativos não são utilizados efetivamente. As principais decisões políticas e as leis que mais afetam os cidadãos não são levadas a julgamento popular. Daí a relevância da figura do representante em nossa República, pois ainda fica nele concentrado o poder de decisão. Desta forma, a efetivação de nosso modelo democrático ainda depende muito da atividade parlamentar, principalmente das votações que são realizadas no Congresso Nacional. Compreender a relação entre representante e representado é a chave para entender os pressupostos do voto aberto e do voto fechado.

\section{A relação entre representante e representado}

Houve uma época em que as decisões tomadas pelo representante seguiam estritamente as diretrizes traçadas pelos representados. Explicava-se a representação através do mandato, termo adotado até hoje na Constituição Federal, mas que não guarda mais qualquer relação com o instituto do Direito Civil. Prevalecia o chamado mandato imperativo:

[...] o mandato imperativo é um tipo histórico de representação, repelida pelo Direito Público moderno, através da qual o eleitor tinha controle sobre a atividade do eleito, ou seja, havia efetivamente um controle jurídico sobre a atividade do eleito. Isto fica claro por causa das instruções dadas a ele, pela possibilidade de revogação do mandato e pela obrigação do eleito prestar contas de seus atos (SOARES, 1998, p. 27).

Este modelo de representação foi abandonado em 1791 pela Constituição Francesa pós-revolucionária, e foi dizimado dos demais parlamentos durante o transcorrer do século XIX. Acreditava-se que ele engessava o parlamentar, limitando exageradamente a sua liberdade.

Porém, o término do mandato imperativo não significou a concessão de poderes ilimitados aos representantes. Se assim fosse, viver-se-ia em uma aristocracia/oligarquia e não em uma democracia. 
O fim do controle jurídico do parlamentar não significa a plena liberdade em suas decisões, pois, afinal, ainda existem o controle político e o social. Estes, por sua vez, só podem ser feitos se houver conhecimento da posição adotada pelo parlamentar. Daí a grande importância na transparência de seu voto como garantia da própria democracia. Esclarece Bobbio (2002, p. 106): "A democracia é a tentativa de tornar o poder visível a todos; é, ou deveria ser, 'poder em público', ou seja, aquela forma de governo em que a esfera do poder invisível está reduzida ao mínimo".

O princípio da publicidade segue a democracia, pois ele deixa transparente o poder, que, desta forma, pode ser controlado. Para Immanuel Kant (apud BOBBIO, 2002, p. 113) (1724-1804), grande filosofo alemão que tantas contribuições trouxe ao Direito, a publicidade é, inclusive, imperativo ético: "todas as ações relativas aos direitos dos outros homens, cuja máxima não é compatível com a publicidade, são injustas". Ou seja, se um homem não pode expressar seu pensamento, sua decisão, é porque, a priori, não seria ela ética.

A Constituição Federal adota expressamente o princípio da publicidade (artigo 37, caput). Porém, nem precisaria, pois este princípio é um postulado lógico da própria democracia.

No texto constitucional o princípio da publicidade encontra-se no capítulo " $D a$ Administração Pública" e também em norma referente ao Poder Judiciário: "todos os julgamentos do Poder Judiciário serão públicos [...]" (artigo 93, IX, CF) e "as decisões administrativas dos tribunais serão motivadas e em sessão pública [...]" (art. 93, X, CF). Isto poderia induzir o jurista a uma interpretação restritiva equivocada, pois a Carta Magna nada diz a respeito do Poder Legislativo. Ora, dever-se-ia excluir este poder da República da incidência do princípio da publicidade? Obviamente que não. Com efeito, o referido princípio alcança todo o Estado Brasileiro, sem exceção. Porém, é necessário encontrar os seus limites, pois nenhum princípio ou regra é absoluto no sistema jurídico contemporâneo.

Como acima foi dito, o representante popular não é mais controlado juridicamente pelos representados, pois a sua liberdade deve ser mantida. Considerando-se este aspecto, em que grau a publicidade necessária ao modelo democrático afeta o voto do parlamentar? Para encontrar esta resposta é preciso entender os pressupostos fáticos e políticos que 
estão por trás do voto secreto e do voto aberto. Para isso, reporta-se ao filósofo inglês John Stuart Mill (1806-1873).

Este pensador é um grande defensor do voto aberto, inclusive para os próprios cidadãos. Em pleno século XIX, em sua obra Consideration on Representative Government, Stuart Mill defende o voto aberto acreditando que, desta forma, o cidadão votaria conforme o interesse da coletividade. Sendo público o voto, todos deveriam prestar contas à coletividade, e, assim, ficariam tolhidos de votar egoisticamente. Para ele, as influências e controle que porventura atingissem o cidadão trariam um mal menor à sociedade:

Mas nos Estados mais adiantados da Europa moderna e especialmente na Inglaterra, o poder de coagir os eleitores declinou e está declinando; e o mau voto é menos de temer por parte de influências a que o eleitor está sujeito às mãos de terceiros do que dos interêsses sinistros e sentimentos desonrosos que lhe pertencem, ou individualmente ou na qualidade de membro de uma classe (MILL, 1964, p. 135).

Ou seja, para Stuart Mill o voto aberto seria uma forma de afastar a irresponsabilidade do votante. Só se deveria adotar o voto secreto se as influências e pressões existentes na sociedade fossem grandes suficientes a interferir na vontade do votante, fazendo com que ele votasse contrariamente à sua consciência. Destaque-se:

Pode acontecer, sem dúvida alguma, que se tentarmos tornar o eleitor responsável ao público pelo próprio voto, fazendo uso de publicidade, ficará praticamente responsável por êle perante algum indivíduo poderoso, cujo interêsse está mais em oposição ao interêsse geral da comunidade do que o do próprio eleitor estaria se, protegido pelo sêgredo, ficasse inteiramente livre de responsabilidade (MILL, 1964, p. 134).

É a influência do "indivíduo poderoso" que justifica o voto secreto. A incapacidade do votante de resguardar-se de coações e pressões de qualquer tipo impossibilitaria o voto livre. Porém, Stuart Mill não acreditava nesta influência, e, por isso, defendia a ampla adoção do voto aberto, inclusive para a escolha dos governantes pelos cidadãos ingleses.

Por outro lado, criticava o voto secreto, pois, se o sigilo do voto permite que o cidadão vote segundo sua própria convicção, não tendo que seguir qualquer orientação de seu empregador, patriarca, marido, etc, permite também que sua convicção seja fruto de uma análise individualista, ou seja, que seu voto seja egoísta, irresponsável: "Os homens 
darão votos desonestos ou mesquinhos por malícia, por melindre, pela rivalidade pessoal, até mesmo por interêsses ou preconceitos de casta ou seita, mais prontamente em segrêdo do que em público"(MILL, 1964, p. 140).

Estes, portanto, são os aspectos fáticos e políticos que legitimam a adoção do voto secreto, ou do voto ostensivo. O primeiro tem a finalidade de resguardar a vontade do votante, permitindo que aja conforme sua conviç̧ão, mesmo que escusa. O outro tem a finalidade de permitir o controle sobre o voto, fazendo com que o parlamentar deva fundamentar racionalmente a sua escolha.

Como se sabe, parte da idéia de Stuart Mill é totalmente absurda face aos ditames da atual Constituição Federal. A Carta Magna estabelece o voto secreto para o cidadão (art. 14, caput) e determina que tal direito não pode ser alterado pelo Poder Constituinte Derivado (art. 60, §4으, II). Porém, esta mesma constituição estabelece várias garantias aos parlamentares, o que revela, ao menos juridicamente, a existência de um escudo capaz de proteger o representante do povo de influências prejudiciais ao voto livre. Assim, seguindo o pensamento de Stuart Mill, considerando a realidade jurídica existente, não poderia o voto aberto ser aplicado aos nossos congressistas?

Se Stuart Mill não convence quanto à aplicabilidade do voto aberto para o cidadão, visto que parte de premissa equivocada de que seriam poucas as influências dos "poderosos" sobre o voto da população, o mesmo não se pode dizer quanto à sua aplicabilidade aos parlamentos da República. A construção feita pelo referido filósofo tomando por base o cidadão inglês, pode, a fortiori, ser adotada em relação aos integrantes de casas legislativas.

O voto aberto é uma forma de obrigar o parlamentar a justificar o seu voto perante o público: "Até mesmo o simples fato de ter de dar contas da própria conduta constitui poderoso estímulo no sentido de adotar conduta da qual seja possível, ao menos, dar conta até certo ponto decente" (MILL, 1964, p. 1939). Assim, por exemplo, se certo deputado federal votou em Severino Cavalcanti para a presidência da Câmara dos Deputados, é totalmente possível que seus eleitores indaguem-no sobre as razões de tal voto. A transparência permite o controle do parlamentar que, sabendo disso, tende a pensar melhor nas razões de seu voto, pois, afinal, poderá ser chamado por seus eleitores ou pela impressa a defendê-lo. É sempre importante destacar que: 
O representante do povo é eleito com lisura e passa a exercer o mandato popular que lhe foi outorgado. Deve, portanto, agir em nome e no interesse do povo; em última análise, deve seguir a vontade popular e agir de acordo com a Constituição Federal e leis infraconstitucionais (PORTA, 2000, p. 150).

Conclui-se que em uma democracia representativa há um vetor que conduz à publicidade dos votos nos parlamentos. Assim é pois ela pressupõe a responsabilidade do parlamentar sobre o seu voto, e a necessidade de uma motivação racional para a tomada de posição. A regra geral, portanto, é o voto aberto, e não o contrário. As influências que o parlamentar sofre, e sabe-se que são várias ${ }^{3}$, não chegam ao ponto de legitimar a adoção do voto secreto. $O$ voto ostensivo é a tendência que um ordenamento democrático deve seguir, sob pena de fomentar a irresponsabilidade do parlamentar, e o seu distanciamento em relação aos anseios populares.

\section{Análise constitucional}

Feitas estas digressões, fundamentais para o prosseguimento do trabalho, pode-se retornar ao texto constitucional. Conforme dito, na Constituição Federal não há dispositivo expresso que determine se o voto do parlamentar deve ser secreto ou ostensivo. Porém, a Carta Magna elenca algumas hipóteses em que o sigilo deverá ser observado:

a) escolha de magistrados, governador de território, presidente e diretores do Banco Central, Procurador-Geral da República (art. 52, III);

b) escolha de chefes de missões diplomáticas (art. 52, IV);

c) deliberação sobre a exoneração, de ofício, do Procurador-Geral da República (art. 52, XI);

d) decretação de perda de mandato (art. 55, §2ㅇ);

e) apreciação de veto presidencial (art. 66, §4우).

Além destes casos expressos, ainda se deve considerar:

3 “Os lobbies são detentores de poder de fato, mas não titulares desse poder; trata-se de um poder de fato, normalmente invisível, e, conseqüentemente, não são passíveis de qualificação como poderes de direito ou titulares do poder político" (MORAES, 2000, p. 133) 
f) a eleição para composição das Mesas da Câmara dos Deputados e do Senado Federal (art. 57, §4ㅇ), conforme salienta a doutrina e dispõe o regimento interno da Câmara dos Deputados (art. 7ㅇ) e o regimento interno do Senado Federal (art. 291, II); g) a hipótese de deliberação sobre a suspensão das imunidades parlamentares durante o estado de sítio (art. $53, \S 8$ ㅇ), também por força da doutrina.

É bom esclarecer que no texto constitucional não se encontra menção alguma quanto ao sigilo das votações acima destacadas (itens $f$ e $g$ ), é a interpretação majoritária que assim as considera. Inclusive, quanto ao artigo 53, §8으, da Constituição Federal, deve-se destacar que o Poder Constituinte não repetiu a expressão "voto secreto", contida no artigo 154, parágrafo único da Constituição Federal de 1967 - teria sido isso um lapso, ou intencionalmente se entendeu por bem mudar a disciplina da matéria? Afinal, tratando-se de deliberação para suspensão de imunidades parlamentares durante o estado de sítio, sabe-se que o voto aberto tenderia a favorecer os interesses do Poder Executivo, que, no estado de sítio, tem o seu poder majorado jurídica e faticamente, podendo influenciar decisivamente na votação. De qualquer forma, trata-se de caso complexo que não será estudado no presente artigo.

Sabe-se que as exceções contidas na Carta Magna, anteriormente elencadas (itens $a$ a e), pretendem preservar o parlamento da influência do Poder Executivo, daí ser o voto secreto o escolhido, na maioria das vezes, em deliberações sobre atos do Presidente da República.

O rol constante na Constituição Federal, dos casos em que a votação sigilosa deve ser observada, é exemplificativo ou taxativo? Considerando o que foi dito no tópico anterior, não resta dúvida de que se trata de rol taxativo, não podendo o legislador infraconstitucional criar outros casos em que seja adotado o voto secreto. Inclusive, a interpretação dada ao art. 57, §4으, da Constituição Federal, bem como ao seu artigo 53, §8으, com o devido respeito, diante do princípio democrático que fundamenta a Carta Magna, está equivocada. A tradição histórica e o costume não poderiam ter feito o intérprete inclinar-se pelo voto secreto nestes casos, pois a Constituição Federal de 1988 estabelece a regra geral do voto aberto.

O primeiro caso histórico, após a promulgação da Constituição Federal de 1988, em que a comunidade jurídica passou a discutir o voto aberto nos parlamentos, decorreu de 
incidente durante o processo de impeachment do então presidente Fernando Collor de Mello.

$\mathrm{Na}$ época, vários doutrinadores teceram comentários sobre o tema, a maioria deles chegando à conclusão de que o voto aberto era um imperativo constitucional que deveria ser observado como regra geral. O Supremo Tribunal Federal manifestou-se sobre a questão através do julgamento do Mandado de Segurança no 21.564-04.

No início da década de 90, o presidente recém eleito, Fernando Collor de Mello, recebeu várias denúncias de corrupção. A crise política agravou-se e os artigos 85 e 86 da Constituição Federal, que disciplinam o processo de impeachment, passaram a ser utilizados pelas instituições democráticas. 0 artigo 86 da Carta Magna estabelece que o juízo de admissibilidade de acusação contra o Presidente da República compete à Câmara dos Deputados. O Presidente só pode ser processado se dois terços dos deputados federais concordarem. Ocorre que o texto constitucional não dispõe se este juízo de admissibilidade deve ser feito por votação secreta, ou aberta.

Instaurada a denúncia contra Fernando Collor de Mello, o Presidente da Câmara dos Deputados encaminhou o procedimento estabelecendo que o juízo de admissibilidade fosse realizado por votação aberta. Face a isso, o então Presidente da República impetrou mandado de segurança perante o Supremo Tribunal Federal pleiteando a votação sigilosa, dentre outras pretensões.

Estava instaurado o conflito. A favor do voto aberto tinha-se o artigo 23 da Lei 1.079/50: "[...] será o mesmo submetido a votação nominal [...]". Porém, os defensores do voto secreto afirmavam que tal dispositivo não havia sido recepcionado pela Constituição Federal de 1988. Do lado deles existia parecer do grande constitucionalista Manoel Gonçalves Ferreira Filho, bem como dispositivo do regimento interno da Câmara dos Deputados que previa o voto secreto nesta hipótese. A discussão foi acirrada. No final, em 23 de setembro de 1992, a corrente pelo voto aberto prevaleceu na Corte Excelsa, por maioria de votos, e os deputados federais, sem o escudo do sigilo, acabaram cedendo à pressão popular e admitiram o processamento do Presidente da República.

\footnotetext{
4 Informações obtidas no site oficial do Supremo Tribunal Federal: http://www.stf.gov.br - acesso em 28 de janeiro de 2007.
} 
O referido incidente histórico é importantíssimo para o presente trabalho porque nas razões proferidas pelos eminentes Ministros do Supremo Tribunal Federal, quando do julgamento do Mandado de Segurança $\mathrm{n}$ - 21.564-0, encontra-se rica análise sobre a ostensividade do voto. Colhe-se do voto do Ministro Carlos Velloso:

\begin{abstract}
Registre-se, ademais, em favor da recepção e aplicabilidade do citado artigo 23, no caso, que o voto ostensivo é o voto responsável, é o voto querido pela Constituição. O voto secreto é exceção ao princípio da publicidade. Montesquieu, no sempre atual 'Espírito das Leis', deixa claro, no capítulo II do Livro II, que a publicidade do voto é lei fundamental da democracia. É o próprio Montesquieu que nos revela que, segundo Cícero, as leis que tornaram secreto o voto constituíram a causa da queda da república romana ('O Espírito das Leis', tradução de Fernando Henrique Cardoso e Leônico Martins Rodrigues, Ed. UnB, 1982, pág. 50). É o que registra, aliás, o Prof. Paulo Bonavides em parecer que nos foi oferecido (STF - MS no 21.564-0, 1992, p. 60).
\end{abstract}

E do voto do Ministro Celso de Mello:

É de registrar, finalmente, que as votações congressuais submetem-se, ordinariamente, ao processo de votação ostensiva, sendo de exegese estrita as normas, de índole necessariamente constitucional, que fazem prevalecer, em hipóteses taxativas, os casos de deliberação sigilosa (STF - MS no 21.564-0, 1992, p. 98).

Antes da manifestação dos Ministros do STF, o ilustre professor Paulo Bonavides já havia exarado sua opinião sobre o tema nos seguintes termos: "A Constituição explicita sempre o teor sigiloso do voto quando ele se faz necessário. Fora daí o entendimento correto é o da publicidade, nomeadamente em se tratando de grandes decisões institucionais" (BONAVIDES, 1993, p. 137).

Desta forma, concluí-se, com base na Ciência Política (vide tópicos 2 e 3) bem como no entendimento dos citados Ministros do STF e no pensamento do professor Paulo Bonavides, que as hipóteses de votação secreta constantes no texto constitucional são restritas e excepcionais. A regra constitucional, portanto, é a ostensividade das votações.

Retomando a introdução do presente trabalho, nota-se que os casos lá exemplificados - eleição de Severino Cavalcanti para a Presidência da Câmara e absolvição de deputados federais em processos disciplinares - amoldar-se-iam justamente aos casos excepcionais previstos no texto constitucional. No primeiro exemplo é possível, através da interpretação, demonstrar que a eleição do presidente da Câmara dos Deputados deve ser 
aberta, pois a Constituição Federal não determinou que ela fosse secreta e a regra geral é a ostensividade. Já quanto ao processo disciplinar, juridicamente não há nada que se possa fazer, pois há norma originária expressa na Constituição Federal (art. 55, §2º), devendo a população contentar-se com tal realidade. Conforme salienta José Afonso da Silva $(2005$, p. 424):

A questão de saber se a votação deve ser secreta ou aberta não oferece dificuldade, porque a Constituição já decidiu como deve ser. No caso, a perda do mandado será decidida pela Casa do imputado, por voto secreto e maioria absoluta. $O$ voto tem que ser secreto. A Casa não pode mudar isso. $O$ voto aberto está fora de cogitação legítima, por mais que isso possa ser tido como desejável. Só emenda constitucional pode mudar esse critério.

Este problema será retomado no item 7. Desde já fica revelada, portanto, a regra constitucional da ostensividade das votações parlamentares, fruto direto do princípio democrático.

\section{Análise infraconstitucional}

Terminado o estudo sobre a Carta Magna, resta, diante da visão positivista adotado no presente trabalho, verificar se as normas hierarquicamente inferiores à Constituição Federal enquadram-se a ela:

\footnotetext{
Por isso têm-se os princípios constitucionais como a síntese dos valores adotados, aceitos ou eleitos pelo corpo social, pela sociedade. Se qualquer sistema, para ter funcionalidade e ser reconhecível, carece de unidade e ordenação, os princípios constitucionais passam a constituir as balizas e ao mesmo tempo os alicerces desse sistema, justamente para dar-lhe concretude, o ser o 'fio condutor' a limitar outra espécie de normas jurídicas (ROSA, 2002, p. 198).
}

Sobre o voto dos parlamentares no Congresso Nacional, os documentos legais de maior importância são os regimentos internos da Câmara dos Deputados e do Senado Federal, pois não existe lei ordinária ou complementar que disponha sobre esta matéria. A Constituição Federal estabelece que compete privativamente à Câmara dos Deputados (art. 51, III) e ao Senado Federal (art. 52, XII) elaborar seus respectivos regimentos internos. Para o professor José Afonso da Silva: 
Criam elas suas leis internas, que disciplinam sua organização sem interferência uma na outra ou de outro órgão governamental. Com o novo texto constitucional, o regimento interno de cada Casa e o regimento interno comum do Congresso Nacional recobram sua importância de principal fonte do Direito Parlamentar (SILVA, 2001, p. 514).

Os regimentos internos disciplinam minuciosamente a votação dos parlamentares. Não poderia ser de outra forma, afinal o voto é o instrumento nuclear da atividade parlamentar. Estes diplomas normativos estabelecem quando a votação poderá ser ostensiva ou secreta (art. 184, RI da Câmara dos Deputados, e art. 289, RI do Senado Federal). Embora os regimentos internos sejam frutos da autonomia do Poder Legislativo, eles também estão subordinados à Constituição Federal, e, portanto, não podem conter dispositivos que a contrariem.

Ocorre que em ambos se encontra disposições questionáveis:

Art. 188. A votação por escrutínio secreto far-se-á pelo sistema eletrônico, nos termos do artigo precedente, apurando-se apenas os nomes dos votantes e o resultado final, nos seguintes casos:

[...]

II - por decisão do Plenário, a requerimento de um décimo dos membros da Casa ou de Líderes que representem esse número, formulado antes de iniciada a Ordem do Dia. ${ }^{5}$

Art. 291. Será secreta a votação:

[...]

III - por determinação do Plenário. ${ }^{6}$

Ora, o que os regimentos internos estão fazendo é criar hipótese de votação secreta inexistente no texto constitucional. As Casas não possuem este poder. Conforme exposto no tópico 4, o rol constante na Carta Magna é taxativo, não sendo possível estendê-lo. Por isso, os dispositivos citados estão eivados do mal da inconstitucionalidade. O Plenário não é competente para determinar os casos em que o escrutínio secreto deve ser observado, pois o próprio Poder Constituinte Originário já realizou tal escolha.

Da mesma forma, quando o regimento interno da Câmara dos Deputados (art. 7ํ) e o regimento interno do Senado Federal (art. 291, II) estabelecem a votação sigilosa para a eleição de suas Mesas, em que pese entendimento contrário, estão adotando modalidade

5 Regimento Interno da Câmara dos Deputados, obtido no site oficial da Casa: http://www.camara.gov.br acesso em 28 de janeiro de 2007.

6 Regimento Interno do Senado Federal, obtido no site oficial da Casa: http://www.senado.gov.br - acesso em 28 de janeiro de 2007. 
de votação que fere a Constituição Federal, pois ela não estabeleceu o voto secreto para esta hipótese.

Ficou demonstrado o problema jurídico-positivo. Os regimentos internos da Câmara dos Deputados e do Senado Federal possuem normas que conflitam com a Constituição Federal. Dispositivos que deverão ser expurgados do sistema jurídico pátrio, por força do princípio da supremacia constitucional.

\section{Outros entes federativos}

É importante, quando se realiza um estudo de caráter constitucional, sempre voltar os olhos aos demais entes da federação, sob pena de limitar a contribuição do trabalho. A análise já feita deve ser aplicada apenas ao Congresso Nacional, ou também às demais casas legislativas da República? Sabe-se que o Brasil possui milhares de Câmaras de Vereadores e vinte e seis Assembléias Legislativas (ressalvando-se o Distrito Federal), daí a relevância do presente tópico.

Dois dispositivos constitucionais são fundamentais à compreensão do problema:

Art. 25. Os Estados organizam-se e regem-se pelas Constituições e leis que adotarem, observados os princípios desta Constituição.

Art. 29. O Município reger-se-á por lei orgânica, votada em dois turnos, com o interstício mínimo de dez dias, e aprovada por dois terços dos membros da Câmara Municipal, que a promulgará. Atendidos os princípios estabelecidos nesta Constituição, na Constituição do respectivo Estado e os seguintes preceitos: [...] (CONSTITUIÇÃO FEDERAL, 1988).

Como se vê, tanto o Estado-membro quanto os Municípios possuem autonomia político-administrativa. Aquele é regido primariamente por uma Constituição, o outro possui uma Lei Orgânica. Estes dois diplomas normativos devem respeitar os princípios constitucionais. Ou seja, a supremacia da Constituição Federal não fica restrita ao âmbito da União, sendo totalmente aplicável aos Estados e Municípios. De acordo com o professor Celso Bastos (1998, p. 306):

O poder constituinte originário, o que elabora a Constituição Federal, é soberano, enquanto o poder constituinte estadual é autônomo. O primeiro não está subordinado a nenhuma limitação jurídica. O segundo atua dentro de uma área de competência, delimitada pela Constituição Federal. 
Embora no texto constitucional não se encontre qualquer dispositivo disciplinando a votação nas Câmaras de Vereadores e nas Assembléias Legislativas, já se sabe que existem dispositivos que regulam tal matéria no âmbito do Congresso Nacional, o que é suficiente para regular a questão também no âmbito estadual e municipal.

Conforme exposto no tópico 4, a Constituição Federal estabelece a regra geral da ostensividade nas votações parlamentares. Os casos em que é ressalvado o escrutínio secreto são excepcionais, consistindo rol taxativo. Entende-se que esta matéria possui natureza nacional, ou seja, não foi colocada na Constituição Federal para alcançar apenas o Congresso Nacional, abrange também os Poderes Legislativos Municipal e Estadual. Este fenômeno ocorre graças ao princípio da simetria. Ele determina que os Estados-membros e os Municípios devem seguir, em sua organização político-administrativa, as disposições constitucionais aplicáveis à União Federal.

Assim, não é possível no âmbito municipal ou estadual criar-se outras hipóteses de escrutínio secreto. A regra, também para eles, é a da ostensividade das votações. Se por acaso, algum diploma municipal ou estadual seguir o exemplo inconstitucional dos dispositivos regimentais da Câmara dos Deputados e do Senado Federal, permitindo que o plenário estabeleça o escrutínio secreto, estar-se-á diante de norma inconstitucional, passível de ser eliminada do sistema jurídico pátrio.

\section{Expectativas sobre o tema}

No final do tópico 4 concluiu-se que as hipóteses excepcionais previstas na Constituição Federal para o escrutínio secreto, dentre elas a do julgamento disciplinar de parlamentar, só poderiam ser alteradas através do Poder Constituinte Derivado, entendimento este esposado, inclusive, pelo professor José Afonso da Silva.

Neste tópico, estudar-se-á qual a possibilidade fática destas alterações serem feitas pelo Congresso Nacional. Qual a tendência no Poder Legislativo, eliminar o voto secreto, ou mantê-lo? Para responder a isso, deve-se mergulhar no direito pré-positivado, nas proposições parlamentares, para verificar o que já existe sobre este tema.

Desde 2001 a Câmara dos Deputados demonstrou interesse em alterar o texto constitucional. Em 9 de maio de 2001, o deputado federal Luiz Antonio Fleury (PTB-SP) 


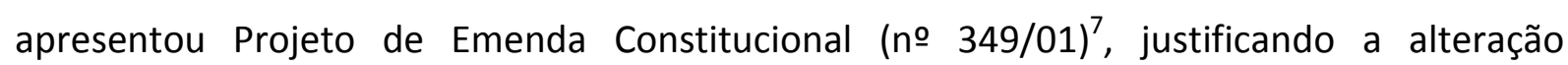
normativa nos seguintes termos:

Pode-se afirmar, sem risco teórico, que o princípio da representatividade popular é incompatível com a votação secreta, impondo ao representante a transparência de seus atos. [...] Será julgado, sim - e o somos todos os dias por nossos atos e palavras - por seu eleitor e pela opinião pública. Assumir posição, a favor ou contra, mas assumindo a responsabilidade pública dessa decisão e não se escondendo atrás de um sigilo que não mais se justifica (CÂMARA DOS DEPUTADOS, 2007).

A referida proposta, conforme sua ementa: "Altera a redação dos arts. 52, 53, 55 e 66 da Constituição Federal para abolir o voto secreto nas decisões da Câmara dos Deputados e do Senado Federal". Em 5 de setembro de 2006, a referida PEC foi aprovada em primeiro turno na Câmara dos Deputados. Seguindo o rito determinado pela Constituição Federal, ela ainda deve ser aprovada em mais um turno na própria Câmara dos Deputados, e depois encaminhada ao Senado Federal, onde também haverá votação em dois turnos.

Desde setembro de 2006 a matéria já foi levada várias vezes ao plenário da Câmara dos Deputados para discussão em segundo turno, porém, não foi ainda apreciada. Trata-se de jogo político, pois, como a emenda constitucional precisa da aprovação de três quintos de seus membros (art. 60, §2ํㅡ, CF), levá-la à votação, em sessão de baixo quorum, é arriscado.

Esta PEC não dispõe sobre a eleição da Mesa da Câmara dos Deputados e do Senado Federal, por isso, mesmo que aprovada, para este caso ainda será adotado o escrutínio secreto. De qualquer forma, se o referido projeto passar a integrar o nosso sistema jurídico, ter-se-á um avanço em nossa democracia, pois as hipóteses de votação secreta serão diminuídas. A expectativa é positiva, portanto, pois ao menos existe a referida PEC tramitando no Congresso Nacional.

\section{Conclusões}

O presente trabalho trouxe modesta contribuição à doutrina pátria, podendo-se destacar o seguinte:

7 Importante salientar que o texto constitucional (artigo 60, I) determinar que as propostas de Emenda Constitucional sejam encaminhadas por um terço dos membros da Câmara dos Deputados, daí o equívoco de atribuir a apenas um parlamentar a proposta acima referida. 
a) Embora a Constituição Federal não estabeleça expressamente a regra da ostensividade da votação dos parlamentares, tal diretriz decorre da adoção do Estado Democrático de Direito; b) As hipóteses constitucionais, em que é ressalvado o escrutínio secreto, são excepcionais e consistem em um rol taxativo;

c) As normas infraconstitucionais não podem ampliar tais hipóteses, sob pena de inconstitucionalidade. No entanto, existem dispositivos nos regimentos internos da Câmara dos Deputados e do Senado Federal que contrariam a Carta Magna;

d) As Constituições Estaduais e as Leis Orgânicas Municipais devem respeitar a regra da ostensividade da votação dos parlamentares, não podendo ampliar o rol taxativo dos casos de escrutínio secreto, estabelecido na Constituição Federal;

e) A tendência no Congresso Nacional é a ampliação das hipóteses do voto aberto. Existe projeto de emenda constitucional ( $n$ o 349/01) que limita os casos do voto secreto, inclusive, já aprovado em primeiro turno na Câmara dos Deputados.

Por fim, cabe ressaltar a importância do Poder Legislativo para a realização do ideal democrático, e a necessidade de que os pesquisadores aprofundem-se no estudo deste poder da República, aumentando-se a produção científica nesta área.

\section{Referências}

BASTOS, Celso Ribeiro. Curso de direito constitucional. São Paulo: Saraiva, 1998.

BOBBIO, Norberto. A teoria das formas de governo. Brasília: Editora Universidade de Brasília, 1997.

BOBBIO, Norberto. Diálogo sobre a república: os grandes temas da política e da cidadania. Rio de Janeiro: Campus, 2002.

Teoria do ordenamento jurídico. Brasília: Editora Universidade de Brasília, 1999.

BONAVIDES, Paulo. O processo por crime de responsabilidade do Presidente da República. In: A OAB e o Impeachment. Brasília: Conselho Federal da OAB, 1993.

BRASIL. Constituição Federal de 1891. Disponível em:

<http://www.presidencia.gov.br/legislacao>. Acesso em: 28 jan. 2007. 
BRASIL. Constituição Federal de 1967. Disponível em:

<http://www.presidencia.gov.br/legislacao>. Acesso em: 28 jan. 2007.

BRASIL. Constituição Federal (1988). Coletânea de Legislação Administrativa. São Paulo: Revista dos Tribunais, 2005.

BRASIL. Regimento Interno da Câmara dos Deputados. Disponível em: <http://www.camara.gov.br>. Acesso em: 28 jan. 2007.

BRASIL. Regimento Interno do Senado Federal. Disponível em: <http://www.senado.gov.br>. Acesso em: 28 jan. 2007.

BRASIL. Supremo Tribunal Federal. Mandado de Segurança no 21.564-0. Relator: Ministro Carlos Velloso, julgamento em 23 de setembro de 1992. Disponível em:

<http://www.stf.gov.br>. Acesso em: 28 jan. 2007.

DALLARI, Dalmo de Abreu. Elementos de teoria geral do Estado. São Paulo: Saraiva, 2001.

IGLESIAS, Francisco. Trajetória política do Brasil: 1500-1964. São Paulo: Companhia das Letras, 1993.

MILL, John Stuart. Considerações sôbre o Govêrno Representativo. São Paulo: IBRASA, 1964.

MONTESQUIEU, Barão de. Do Espírito das Leis. São Paulo: Martin Claret, 2002.

MORAES, Alexandre. Reforma Política do Estado e Democratização. Revista de Direito Constitucional e Internacional, São Paulo, v. 8, n. 32, jul./set. 2000.

PORTA, Marcos de Lima. A noção jurídica da República. Revista de Direito Constitucional e Internacional, São Paulo, v. 8, n. 32, jul./set. 2000.

ROSA, Márcio Fernando Elias. Princípios Constitucionais na Concepção Sistêmica do Ordenamento Jurídico. Revista de Direito Constitucional e Internacional, São Paulo, v. 10, n. 39, abr./jun. 2002.

SILVA, José Afonso da. Comentário Contextual à Constituição. São Paulo: Malheiros, 2005. . Curso de Direito Constitucional Positivo. São Paulo: Malheiros, 2001.

SOARES, Marcos Antônio Striquer. O plebiscito, o referendo e o exercício do poder. São Paulo: Instituto Brasileiro de Direito Constitucional, 1998. 
